\title{
STANDARDIZATION OF THE IL-1 COMITOGENIC ASSAY USING THYMOCYTES FROM LPS-SENSITIVE MOUSE STRAINS
}

\author{
S. R. DALMAU* \& C. S. FREITAS
}

Instituto Nacional de Câncer, Pesquisa Básica e *CEMO, Praça Cruz Vermelha 23/69 andar, 20230

Rio de Janeiro, RJ, Brasil

The thymocyte proliferative assay in the presence of lectins has been used to measure Interleukin 1 (IL-1) activity in biological samples (I. Gery et al., 1972, J. Exp. Med:, 136: 128). A modification of this assay was initially proposed aiming at the measurement of IL-2 activity (J. Shaw et al., 1978, J. Immunol., 120: 1967), and more recently both murine Tumour Necrosis Factor $\alpha$ (TNF $\alpha$ ) (G. E. Ranges et al., 1988, J. Exp. Med., 167: 1472) and IL-6 (M. Helle et al., 1988, Eur. $J$. Immunol., 18: 957) were also shown to be capable of stimulating thymocyte proliferation in the presence of lectins.

When attempting to standardize a sensitive assay, an important variable is the choice of a lectin with a poor proliferative effect on thymocytes but a good costimulatory activity in association with the factors to be measured. Both phytohemagglutinin (PHA) and concanavalin $A$ (Con $A$ ) have been used in thymocyte proliferative assays, their concentration depending on the source and kind of commercially available preparations. Bacterial lypopolysaccharides (LPSs) represent some of the most potent monocyte/macrophage (Mo) activators, and have often been used to induce monokine secretion, thus contaminating Mo culture supernatants. Thymocytes from LPS-unsensitive mouse strains such as $\mathrm{C} 3 \mathrm{H} / \mathrm{HeJ}$ have therefore been preferentially used in costimulatory assays, in order to avoid putative endogenous monokine production with a consequent monokine overestimation in the biological samples. Since $\mathrm{C} 3 \mathrm{H} / \mathrm{HeJ}$ mice represent a difficult strain to be housed, not always available, we tested the potential use of seven different mouse strains in the costimulatory assay, in particular their

Financial support: Campanha Nacional de Combate ao Câncer.

Received September 11, 1989.

Accepted January 30, 1990. threshold of thymocyte sensitivity to lectins and the influence of LPS in the proliferative assay.

Initially, two to three months old male animals from one outbred (SW) and seven inbred (AKR/J, Balb/C, B10A/J, CBA/J, $\mathrm{C} 3 \mathrm{H} / \mathrm{HeJ}, \quad \mathrm{C} 57 \mathrm{Bl} / 10 \mathrm{~J}$ and $\mathrm{DBA} / 2)$ mouse strains were used as thymocytes source. Two cellular concentrations $\left(5 \times 10^{5}\right.$ and $5 \times 10^{6}$ cells $/ \mathrm{ml}$ ) were stimulated with either ConA (Sigma Chem. Co., St. Louis, C-2010) or PHA-M (Sigma, L-8887) at the doses of 1.0 , 2.5 , and $6.25 \mu \mathrm{g} / \mathrm{ml}$, in RPMI 1640 medium containing $5 \times 10^{, 5} \mathrm{M} 2$-mercaptoethanol (complete medium) and $2.5 \%$ inactivated human $\mathrm{A}^{+}$serum (H. Northoff et al., 1986, Immunol. Today, 7: 126), in 96 well flat bottom plates (final volumes of $0.2 \mathrm{ml}$ ), for $68 \mathrm{~h}$ in a humidified $5 \% \mathrm{CO}_{2}$-air mixture. Tritiated thymidine $\left({ }^{3} \mathrm{H} \mathrm{TdR}\right.$, specific activity $\left.2 \mathrm{Ci} / \mathrm{mmole}\right)$ was added for the last $6 \mathrm{~h}$ of culture $(0.5 \mu \mathrm{Ci} /$ well in $25 \mu \mathrm{l}$ ) and incorporation measured by liquid scintillation counting in a toluene-PPO-POPOP cocktail.

With the eight strains used, only thymocytes at the highest concentration $\left(5 \times 10^{6}\right.$ cells $\left./ \mathrm{ml}\right)$ were able to proliferate in response to ConA alone (Table); excluding AKR, all of the strains tested presented a poor proliferative response to $1 \mu \mathrm{g} / \mathrm{ml}$ Con $\mathrm{A}$ but an intense response to $2.5 \mu \mathrm{g} / \mathrm{ml}$ Con A (excluding C57 Bl/10J), showing that the former or even a lower dose must be carefully chosen for use in the comitogenic assay. At the lowest cellular concentration $\left(5 \times 10^{5} \mathrm{cells} / \mathrm{ml}\right.$, neither proliferative nor IL-1 comitogenic activities could be observed with both lectins (data not shown). This lack of comitogenicity at low thymocyte concentrations is a characteristic of IL-1 activity, since IL-2 was shown to be able of strongly costimulate with lectins in this condition (J. Shaw et al., loc. cit.). 
TABLE

Proliferative response of thymocytes from different mouse strains to Con $\Lambda$

Strain

Concanavalin A $(\mu \mathrm{g} / \mathrm{mi})$

\begin{tabular}{lrrrr} 
& & 1 & 2.5 & 6.25 \\
\hline $\mathrm{AKR} / \mathrm{J}$ & $710 \pm 36$ & $19284 \pm 2849$ & $44803 \pm 1120$ & $49163 \pm 1274$ \\
$\mathrm{Balb} / \mathrm{c}$ & $675 \pm 62$ & $4575 \pm 103$ & $29227 \pm 2151$ & $49045 \pm 301$ \\
$\mathrm{~B} 10 \mathrm{~A} / \mathrm{J}$ & $580 \pm 25$ & $1717 \pm 157$ & $15424 \pm 3338$ & $11011 \pm 1468$ \\
$\mathrm{CBA} / \mathrm{J}$ & $690 \pm 42$ & $984 \pm 040$ & $22794 \pm 5004$ & $43613 \pm 2772$ \\
$\mathrm{C} 3 \mathrm{H} / \mathrm{HeJ}$ & $560 \pm 83$ & $2210 \pm 206$ & $21028 \pm 1066$ & $51040 \pm 134$ \\
$\mathrm{CS7B1} / 10 \mathrm{~J}$ & $510 \pm 35$ & $1000 \pm \quad 82$ & $5239 \pm 1153$ & $22421 \pm 648$ \\
$\mathrm{DBA} / 2$ & $625 \pm 58$ & $2584 \pm \quad 32$ & $26080 \pm 10$ & $36869 \pm 4554$ \\
$\mathrm{SW}$ & $815 \pm 60$ & $4083 \pm 223$ & $35845 \pm 2429$ & $51269 \pm 3860$ \\
\hline
\end{tabular}

Thymocyte suspensions $\left(5 \times 10^{6} / \mathrm{ml}\right)$ were cultured for $68 \mathrm{~h}$ in the absence or presence of ConA at diverse doses, and proliferation assessed by the ${ }^{3} \mathrm{H}$ TdR uptake $(0.5 \mu \mathrm{Ci} /$ well $)$ for the last $6 \mathrm{~h}$ of culture. Data are expressed as the mean cpm of duplicates \pm SLM.

No significant proliferation up to $6.25 \mu \mathrm{g} / \mathrm{ml}$ PHA-M was seen even in the highest cellular concentration (data not shown). Our failure in getting good proliferative indexes also when titrating IL-1 containing samples with PHA in the dose interval of 1.0 to $6.25 \mu \mathrm{g} / \mathrm{ml}$ (with 5 to $7.5 \times 10^{6}$ thymocytes $/ \mathrm{ml}$ ) led us to test increasing PHA-M doses. As can be seen in Figs. A and B, PHA-M alone, in doses as high as $40 \mu \mathrm{g} / \mathrm{ml}$ (controls), generated relatively poor thymocyte mitogenic responses, even if the ${ }^{3} \mathrm{H} \mathrm{TdR}$ incorporation time was extended to $24 \mathrm{~h}$. However, optimal comitogenic responses were achieved at the 20 to $40 \mu \mathrm{g} / \mathrm{ml}$ dose interval for both mouse strains tested (Balb/C and $\mathrm{C} 3 \mathrm{H} / \mathrm{HeJ}$ ). Figs. $\mathrm{A}$ and $\mathrm{B}$ also show that LPS alone or in association with PHA was unable to promote thymocyte proliferation either with LPS-sensitive (Balb/C) or unsensitive $(\mathrm{C} 3 \mathrm{H} / \mathrm{HeJ})$ animals, in the conditions of this assay.

Once established that PHA-M was more suitable than Con A to be used as a comitogen in the thymocyte proliferative assay, due to its lower mitogenic potency associated to a good costimulatory capacity in a large dose range $(10-50 \mu \mathrm{g} / \mathrm{ml})$, we tested other PHA derivatives, in an attempt to obtain best comitogenic indexes. Two forms of the PHA protein moiety (PHA-P, Sigma L-8754 and L-9017), and the leucoagglutinin moiety of PHA subunits (PHA-L, Sigma L-2769) were tested for costimulatory capacity with pure human recombinant IL-1 (rhIL-1, Hoffman-La Roche, kindly given by Dr Richard Peck, Basel, SW). Results shown in Fig. $\mathrm{C}$ confirm an optimal dose range of $20.40 \mu \mathrm{g} / \mathrm{ml}$ for $\mathrm{PHA}-\mathrm{M}$, now assayed with a pure rhIL-1 source, instead of a crude supernatant which could bear a mixture of monokines capable of a putative synergistic action. From the four PHA forms tested, the two forms of PHA-P seemed to better costimulate thymocyte proliferation in response to pure $\mathrm{rhIL-1}$, at the dose range of $10-20 \mu \mathrm{g} / \mathrm{ml}$. Fig. $\mathrm{C}$ also shows that the pure rhlL-1 itself can act as a slight mitogen for murine thymocytes, in the absence of lectins.

The proliferative response to exogenous IL.1 in the presence of mitogens (PHA or $\operatorname{Con} A$ ), with thymocytes from one to three months old mice, has been ascribed essentially to mature, ready to leave thymus, medullar peanut agglutinin negative ( $\mathrm{PNA}^{-}$) lymphocytes. It would correspond both to this subpopulation capacity of producing $I \mathrm{~L}-2$ in response to mitogens (P. J. Conlon et al., 1982, J. Immunol., 128: 797; D. F. Hanson et al., 1983, J. Immunol., 130:216) and of enhancing the expression of $I L-2$ receptors under the synergistic action of IL-1 and IL-2, independent of mitogen presence (D. N. Mannel et al., 1985, J. Immunol, 134: 3108). The predominant cortical $\mathrm{PNA}^{+}$thy mocyte sub population (approximately $85 \%$ of total thymocytes), unable to proliferate in response to Con A or PHA (P. J. Conlon et al., loc. cit; B. G. D. Bodeker et al., 1980, Eur. J. Immunol., 10:702), was shown not capable of producing IL-2 when stimulated by mitogen plus IL-1, while its ability to proliferate in response to IL-2, alone or in addition to mitogen (ConA), is uncertain (P. J. Conlon et al., loc. cit.; B. G. D. Bodeker et al., loc. cit.). 


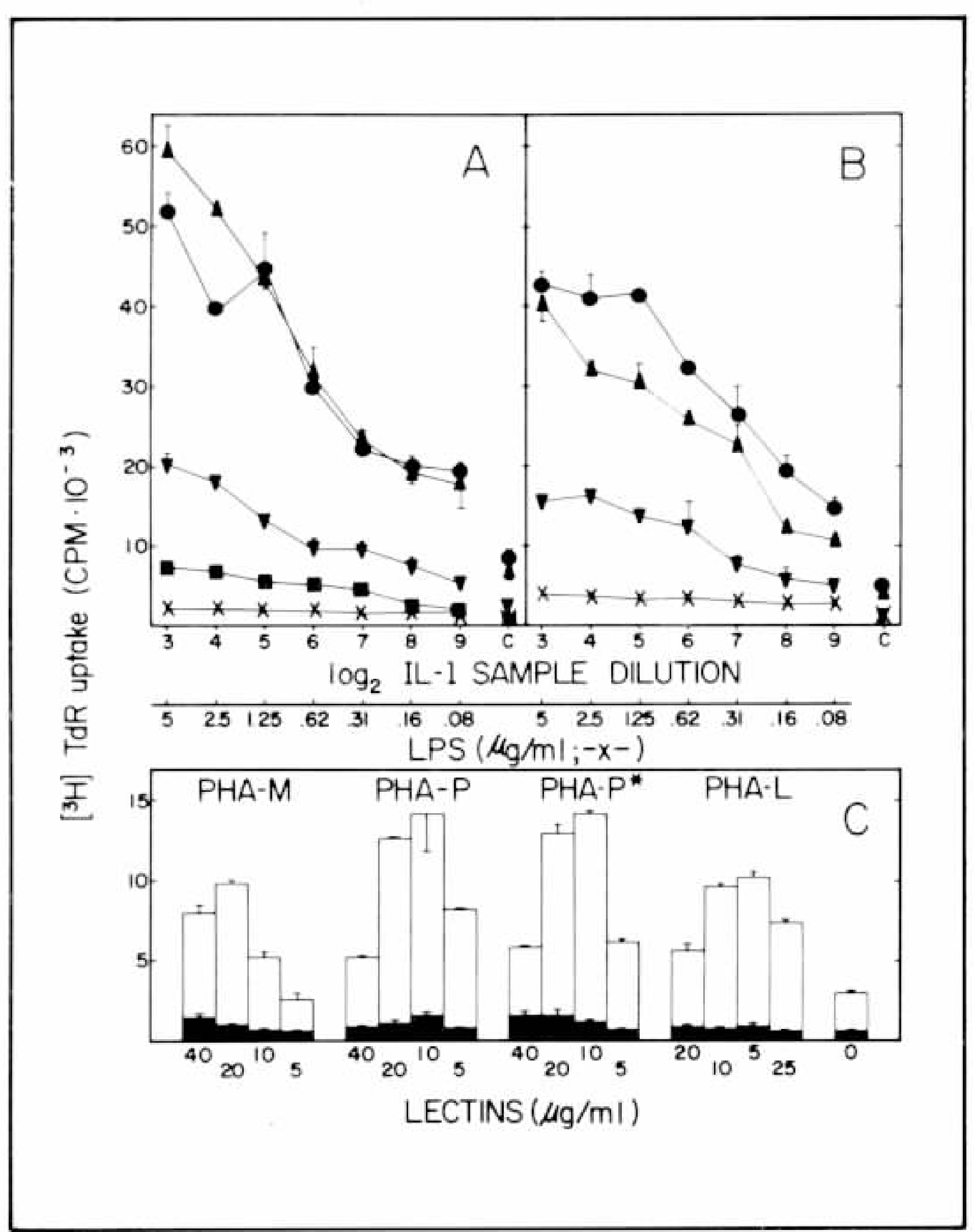

Proliferative response of thymocytes from a LPSsensitive and a LPS-unsensitive mouse strain to PHA, in addition to IL-1 or LPS. Thymocyte suspensions $\left(7.5 \times 10^{6} / \mathrm{ml}\right)$ were cultured with diverse PHA forms and doses, for $72 \mathrm{~h}$ (Figs. A and B) or $96 \mathrm{~h}$ (Fig. C); proliferation was assessed by the ${ }^{3} \mathrm{H}$ TdR uptake for the last $24 \mathrm{~h}$ of culture. Figs. A and B: curves obtained with $\mathrm{Balb} / \mathrm{c}$ (A) and $\mathrm{C} 3 \mathrm{H} / \mathrm{HeJ}$ (B) thymocytes, in response to a serially two-fold diluted crude IL-1 source $(10 \mu \mathrm{g} / \mathrm{ml}$ LPS-stimulated human Mo monolayer supernatant). PHA-M (Sigma L-8887) at $5 \mu \mathrm{g} / \mathrm{ml}$ $(\bullet), 10 \mu \mathrm{g} / \mathrm{ml}(\boldsymbol{\nabla}), 20 \mu \mathrm{g} / \mathrm{ml}(\boldsymbol{\Delta})$ and $40 \mu \mathrm{g} / \mathrm{ml}(\bullet)$. Curves with LPS $(-\mathrm{x}-$ ) (Sigma L-4130) in the presence of PHA-M at $10 \mu \mathrm{g} / \mathrm{ml}$ (A) or $20 \mu \mathrm{g} / \mathrm{ml}$ (B). Controls (C) represent thymocyte response to lectin alone or LPS alone $(5 \mu \mathrm{g} / \mathrm{ml})$ in the absence of IL-1. Fig. C: Balb/c thymocyte proliferative response to PHA-M, PHA-P (Sigma L-8754), PHA-P* (Sigma L-9017) and PHA-L (Sigma L-2769) at diverse doses, in the presence (opened bars) or absence (closed bars) of $25 \mathrm{U} / \mathrm{ml}$ rhIL-1 (5 U/well). Data expressed as the mean $\mathrm{cpm}$ of duplicates \pm SEM.

Thus, it could be suggested for the thymocyte comitogenic assay a mechanism involving the mitogen participation in the production of IL-2, which would in turn, together with the added IL-1, take part on both an enhancement of IL-2 receptors expression and a $\mathrm{PNA}^{-}$cells induction to proliferation.

While PHA specifically binds Galactose $\beta 1 \rightarrow 4 \quad \mathrm{~N}$-acethyl-Glucosamine residues on cellular membrane glycoproteins, Con A is a Mannose $\alpha 1 \rightarrow$ linked oligosaccharide-specific agglutinin (A. M. Wu et al., 1988, Lectins vol. 6, p. 723, Bog-Hansen \& Freed Eds., Sigma Chem. Co., St. Louis). The higher magnitude of murine thymocyte proliferative response to the last mitogen could be explained by a higher frequency, on murine thymocyte surfaces, of Mannose $\alpha 1 \rightarrow$ linked oligosaccharidecontaining activation glycoproteins, although evidence of such a distribution is still lacking. Work is also required to verify if the various maturation subsets of thymocytes (carrying different associations of surface antigens, for instance, CD4, CD8 and CD45) are preferentially bound and activated by Con A or PHA, or even if the difference lies on a preferential binding of mitogen to auxiliary stromal cells contaminating thymic lymphocyte preparations and putatively taking part of the observed response.

In conclusion, we suggest that not only LPS-unsensitive mouse strains, but also the LPS-sensitive ones, can be used as a thymocyte source for the IL-1 assay. Analysis of the thymocyte response to lectins points out PHA (in special the PHA-P form) as the lectin of choice, since a very strict ConA concentration must be established, in accordance to the mouse strain employed, in order to prevent elevated controls with consequent low stimulatory indexes.

Acknowledgements: To Dr Lucia de La Roque for revising the original manuscript and Mr Wanderley B. dos Santos for drawing the graphs. 